\title{
Net transfer of nutrients to the duodenum and disappearance of $n$-alkanes in the reticulo-rumen and the hindgut of sheep fed grass/legume combinations
}

\author{
Abdelhafid Keli†, Genaro Olmosł, Antonio de Vega* and José A. Guada \\ Departamento de Producción Animal y Ciencia de los Alimentos, Universidad de Zaragoza, Miguel Servet 177, 50013 \\ Zaragoza, Spain \\ (Submitted 14 December 2011 - Final revision received 26 July 2012 - Accepted 31 July 2012 - First published online 21 September 2012)
}

\section{Abstract}

An experiment was carried out to examine the effect of increasing the proportion of Wimmera ryegrass hay in a lucerne hay-based diet on net transfer of nutrients to the intestine, and on the disappearance of $n$-alkanes in the reticulo-rumen and the hindgut of sheep. Following a latin square design, four adult ewes were fed 1:0, 0·33:0 67, 0.67:0.33 and 0:1 proportions of legume and grass. Increasing the proportion of ryegrass in the diet linearly decreased the intake of $\mathrm{DM}(P=0 \cdot 017)$, organic matter $(P=0.021)$ and N $(P=0 \cdot 001)$. However, neutral-detergent fibre intake was not affected $(P=0 \cdot 148)$, nor was its digestibility coefficient $(P>0 \cdot 10)$. Diet had no effect on duodenal flows of nutrients $(P>0 \cdot 10)$, although the proportion of $\mathrm{N}$ intake (NI) recovered at the duodenum as non- $\mathrm{NH}_{3} \mathrm{~N}$ (NAN) increased linearly with Lolium rigidum in the diet $(P=0.002)$. Full recovery of $\mathrm{NI}$ as NAN was achieved at $\mathrm{NH}_{3}$ concentrations in the rumen below $110 \mathrm{~g} / \mathrm{l}$. Microbial $\mathrm{N}$ contribution to NAN varied in a quadratic manner $(P<0.05)$ with the proportion of grass in the diet, although efficiency of microbial synthesis was not affected $(P>0 \cdot 10)$. Duodenal recovery of consumed $n$-alkanes was not affected by diet and was complete for those present in higher concentrations in the forages. Isolated rumen bacteria contained significant amounts of $n$-alkanes, contributing to the duodenal flow of these hydrocarbons in variable proportions depending on the diet consumed.

\section{Key words: $\boldsymbol{n}$-Alkanes: Duodenum: Nutrients: Rumen bacteria}

Net transfer of ingested protein to the duodenum (in the form of microbial protein, undegraded plant protein and endogenous protein) is complete only when the plants contain approximately $210 \mathrm{~g}$ crude protein (CP)/ kg digestible organic matter (DOM) or less ${ }^{(1)}$. Above this threshold, there is net loss of protein with potentially large amounts of ingested $\mathrm{N}$ lost as $\mathrm{NH}_{3}$ across the rumen wall. Legumes usually exceed this $\mathrm{CP}$ content, and hence including a grass in the diet might minimise $\mathrm{N}$ losses. The amount of protein reaching the abomasum when animals are fed different grass/legume mixtures $^{(2)}$ is largely unknown, with most of the work having been carried out with silages and dairy animals ${ }^{(3-5)}$. Lucerne and Wimmera ryegrass (Lolium rigidum) are important resources of integrated sheep farming systems in many semi-arid areas of the world, but there is no information about net transfer of $\mathrm{N}$ to the duodenum when these are fed in combination.
The use of $n$-alkanes as markers of diet selection and intake in grazing animals ${ }^{(6,7)}$ is based on evidence that faecal recovery is related to chain length ${ }^{(6-8)}$, which allows correcting for the incomplete faecal recovery of a determined hydrocarbon by dosing a selected alkane of similar chain length. Incomplete recovery of $n$-alkanes in faeces can be due to losses in the reticulo-rumen, in post-ruminal compartments or in both. Studies dealing with ruminal disappearance of $n$-alkanes are scarce ${ }^{(8-11)}$, but they suggest that losses in the reticulo-rumen are minimal, if any. If this is the case, these hydrocarbons could be confidently used as duodenal flow ${ }^{(12)}$ or rumen transit markers ${ }^{(13)}$, regardless of their faecal recovery. Feeding conditions (diet type, feeding regimen, level of intake, etc.) may affect faecal recovery $^{(14)}$, although the effect of diet is unclear ${ }^{(6,15)}$. Whether duodenal recovery is also affected by diet characteristics remains unknown.

Abbreviations: ADF, acid-detergent fibre; ADL, acid-detergent lignin; CP, crude protein; D1, 100\% lucerne; D2, 67\% lucerne and 33\% ryegrass; D3, 33\% lucerne and 67\% ryegrass; D4, $100 \%$ ryegrass; DMI, DM intake; DOM, digestible organic matter; DOMI, DOM intake; LAB, liquid-adherent bacteria; MPS, microbial protein synthesis; NAN, non-ammonia nitrogen; NDF, neutral-detergent fibre; NI, nitrogen intake; OM, organic matter; OMADR, organic matter apparently digested in the rumen; OMI, organic matter intake; OMTDR, organic matter truly digested in rumen; SAB, solid-adherent bacteria; VFA, volatile fatty acids.

*Corresponding author: A. de Vega, fax +34976 761590, email avega@unizar.es

†Present address: Département des Productions Animales et de Pastoralisme, École Nationale d'Agriculture, B.P. S/40, Meknès, Morocco. $\ddagger$ Present address: Colegio de Postgraduados, Campus SLP, Iturbide \# 73 Salinas de Hidalgo, SLP 78600 , Mexico. 
The aim of the present work was to examine the effect of different proportions of lucerne and Wimmera ryegrass in the diet on net transfer of nutrients, particularly protein, to the intestine, and on disappearance of $n$-alkanes in the reticulo-rumen and the hindgut of sheep.

\section{Experimental methods}

\section{Animals and diets}

A total of four non-pregnant, non-lactating adult Rasa Aragonesa ewes, fitted with rigid ruminal $(5 \mathrm{~cm}$ internal diameter) and T-shaped duodenal cannulae, and with an average initial live weight of 54.0 (SEM 2.88$) \mathrm{kg}$, were used. They were allocated, following a latin square design, to four treatment groups consisting of different proportions of lucerne (Medicago sativa) hay and ryegrass (L. rigidum) hay, both chopped to $5 \mathrm{~cm}$ (1.00 lucerne (D1), 0.67 lucerne and 0.33 ryegrass (D2), 0.33 lucerne and 0.67 ryegrass (D3) and 1.00 ryegrass (D4)). At 1 month before the experiment, the sheep were treated with Albendazol $(10 \mathrm{ml})$ to control internal parasites. Water and mineral blocks were available at all times throughout the experimental period. Animals were handled according to criteria from the European Union for the care and use of laboratory animals in research, and the experimental protocol was approved by the Ethical Committee for Animal Research of the University of Zaragoza. The chemical composition and alkane concentration of lucerne and ryegrass are shown in Table 1.

\section{Experimental management}

After implantation of the duodenal and ruminal cannulae in the animals, a recovery period of 3 weeks was allowed. Then, the first run of the latin square was started, which lasted for $26 \mathrm{~d}$, of which the first $14 \mathrm{~d}$ were for adaptation to

Table 1. Chemical composition ( $\mathrm{g} / \mathrm{kg} \mathrm{DM})$ and mean concentration of $n$-alkanes $(\mathrm{mg} / \mathrm{kg} \mathrm{DM})$ in lucerne and ryegrass

\begin{tabular}{lrr}
\hline & Lucerne & Ryegrass \\
\hline Organic matter & 893 & 915 \\
Crude protein & 160 & 43 \\
Neutral-detergent fibre & 446 & 578 \\
Acid-detergent fibre & 339 & 313 \\
Acid-detergent lignin & 71 & 37 \\
Alkane & & \\
$\mathrm{C}_{23}$ & 2.0 & 5.3 \\
$\mathrm{C}_{24}$ & $0 \cdot 8$ & 1.4 \\
$\mathrm{C}_{25}$ & $7 \cdot 1$ & 30.3 \\
$\mathrm{C}_{26}$ & 1.4 & 2.6 \\
$\mathrm{C}_{27}$ & 24.3 & 49.8 \\
$\mathrm{C}_{28}$ & 6.0 & 6.0 \\
$\mathrm{C}_{29}$ & 148.8 & 114.7 \\
$\mathrm{C}_{30}$ & 14.1 & 8.0 \\
$\mathrm{C}_{31}$ & 396.0 & 147.7 \\
$\mathrm{C}_{32}$ & 9.4 & 2.9 \\
$\mathrm{C}_{33}$ & 31.3 & 21.8 \\
$\mathrm{C}_{35}$ & 1.3 & 1.7 \\
$\mathrm{C}_{36}$ & 0.4 & 0.6 \\
\hline
\end{tabular}

the diets. During the adaptation period, sheep were housed in individual pens $(110 \mathrm{~cm} \times 90 \mathrm{~cm})$ with slatted floors. The experimental diets were offered once daily (at 09.00 hours, for 24-h clock) at a restricted level (95\% of ad libitum intake), which was set for each animal during the adaptation period, in order to minimise refusals. Lucerne and ryegrass were offered in separate troughs. During the last $4 \mathrm{~d}$ of the adaptation period, samples of lucerne and ryegrass were ruminally incubated in polyester bags $(45-\mu \mathrm{m}$ pore size) for up to $96 \mathrm{~h}$. After the adaptation period, animals were placed in metabolism crates ( $118 \mathrm{~cm}$ long, $46 \mathrm{~cm}$ wide and $73 \mathrm{~cm}$ high) and a 7-d digestibility balance was performed after a 3-d adaptation period. Animals in metabolism crates were fed at every $4 \mathrm{~h}$ (at 09.00, 13.00, 17.00, 21.00, 01.00 and 05.00 hours, for 24-h clock) by means of automatic feeders. From 1 week before and until the end of the balance period, a once-daily dose of $1.5 \mathrm{~g}$ of paper pellets containing equal amounts of dotriacontane $\left(\mathrm{C}_{32} ; 79.3\right.$ ( $\left.\operatorname{sem} 4.22\right) \mathrm{mg} /$ pellet) and hexatriacontane $\left(\mathrm{C}_{36} ; 77 \cdot 2\right.$ (SEM 4.60$) \mathrm{mg} /$ pellet) was given to the animals with a dosing gun, just before the morning feeding (09.00 hours).

During the second day of the adaptation period to metabolism crates, $1000 \mathrm{ml}$ of rumen contents were obtained at 09.00 hours (before feeding) to isolate background samples of liquid- (LAB) and solid-adherent bacteria (SAB). Another sample of duodenal digesta was also obtained as background reference for the analyses of flow markers ( $\mathrm{Cr}$ for liquid and $\mathrm{Yb}$ for solid phase). In the second day of the balance trial, infusion of $4 \mathrm{ml} / \mathrm{h}$ of a Cr-EDTA solution $(1 \mathrm{~g} / \mathrm{l})$ and $4 \mathrm{ml} / \mathrm{h}$ of a $\mathrm{YbCl}_{3}$ solution $(1 \mathrm{~g} / \mathrm{l})$ was started, using a peristaltic pump (Gilson Minipuls 2) with separate lines, to provide $2 \mathrm{mg} / \mathrm{kg}$ live weight per $\mathrm{d}$ of both $\mathrm{Cr}$ and $\mathrm{Yb}$. After $3 \mathrm{~d}$, a 5 -d dose of labelled ammonium sulphate $\left(10 \%\right.$ atoms ${ }^{15} \mathrm{~N}$; Isotec, Inc.) was incorporated into the Cr-EDTA solution to provide $1.5 \mathrm{mg}$ of ${ }^{15} \mathrm{~N} / \mathrm{g} \mathrm{N}$ intake (NI) as microbial marker. The infusion of all three markers was maintained until the end of the experimental period. This meant that flow markers $\left(\mathrm{Cr}\right.$-EDTA and $\mathrm{YbCl}_{3}$ ) were infused for $6 \mathrm{~d}$ before duodenal sampling and labelled ammonium sulphate for $3 \mathrm{~d}$.

During the digestibility balance period, daily samples of lucerne and ryegrass (and refusals when they occurred) were taken and pooled for the whole period. Half of each sample was dried at $60^{\circ} \mathrm{C}$ for $48 \mathrm{~h}$ for $\mathrm{DM}$ determination, and the other half was kept for chemical composition (organic matter (OM), CP, neutral-detergent fibre (NDF), acid-detergent fibre (ADF; except refusals) and acid-detergent lignin (ADL; except refusals)) and alkane analysis, after grinding through a 1-mm screen. Faeces were collected daily and a subsample ( $5 \%$ on weight basis) was taken and kept frozen $\left(-20^{\circ} \mathrm{C}\right)$ until the end of the collection period. The subsamples from the $7 \mathrm{~d}$ were pooled to a single sample per animal and then freeze-dried for analysis of chemical composition (OM, CP, NDF and $n$-alkanes). Sub-samples of daily faeces were also taken for oven drying at $60^{\circ} \mathrm{C}$ for $48 \mathrm{~h}$ to estimate faecal DM output.

The last $2 \mathrm{~d}$ after the digestibility balance were assigned to sampling of duodenal digesta, which was performed at 6-h intervals. Individual samples were kept at $4{ }^{\circ} \mathrm{C}$ until the end 
of the sampling period, then pooled on an animal basis and frozen at $-20^{\circ} \mathrm{C}$. Those samples were thawed and three sub-samples were taken: whole digesta, and its solid and liquid phases (after straining through polyester bags with $45-\mu \mathrm{m}$ pore size). The sub-samples were again frozen at $-20^{\circ} \mathrm{C}$ and then freeze-dried and ground through a $1-\mathrm{mm}$ screen for chemical composition (whole digesta and its solid fraction only) and $\mathrm{Cr}$ and $\mathrm{Yb}$ analysis. Immediately after the last duodenal sample was taken, rumen emptying was carried out, the weight of rumen contents was recorded and samples of $\mathrm{LAB}$ and $\mathrm{SAB}$ were isolated for ${ }^{15} \mathrm{~N}$-enrichment determination. Samples for chemical composition studies (DM, OM, CP and NDF) were also taken, dried at $60^{\circ} \mathrm{C}$ for $48 \mathrm{~h}$ and ground through a $1-\mathrm{mm}$ screen. The $\mathrm{pH}$ of rumen liquor was recorded, and samples for analysis of volatile fatty acids (VFA) and $\mathrm{NH}_{3}$ concentrations were also taken. The sampling process was as quick as possible, and at the end the remaining rumen contents were immediately returned to the corresponding sheep. The average time each sheep remained 'empty' was about half an hour.

The experimental management was the same for the other three periods of the latin square, and live weight was recorded for all animals at the same time, at the beginning and the end of each period.

Samples for VFA analysis were prepared by adding $1 \mathrm{ml}$ of deproteinising solution $(0.2 \%(\mathrm{w} / \mathrm{v})$ of mercuric chloride, $2 \%(\mathrm{v} / \mathrm{v})$ of orthophosphoric acid and $0 \cdot 2 \%(\mathrm{w} / \mathrm{v})$ of 4-methyl valeric acid) to $4 \mathrm{ml}$ of rumen contents strained through four layers of cheesecloth and preserved frozen $\left(-20^{\circ} \mathrm{C}\right)$ until analysis. For the determination of $\mathrm{NH}_{3}$ analysis, $5 \mathrm{ml}$ of $0 \cdot 1 \mathrm{M}-\mathrm{HCl}$ were added to $5 \mathrm{ml}$ of filtered rumen digesta and preserved frozen $\left(-20^{\circ} \mathrm{C}\right)$ until analysis.

Isolation of bacterial fractions (LAB and $\mathrm{SAB}$ ) from both blank and ${ }^{15} \mathrm{~N}$-labelled ruminal samples was carried out as described by Martin et al. ${ }^{(16)}$. Both LAB and SAB were frozen at $-20^{\circ} \mathrm{C}$ and then freeze-dried to determine their chemical composition (OM and $\mathrm{N}$ ) and ${ }^{15} \mathrm{~N}$ abundance. The concentration of $n$-alkanes in LAB samples was also determined.

\section{Marker techniques}

Cr-EDTA was prepared by the methods of Downes \& McDonald $^{(17)}$, and $360 \mathrm{ml}$ of the Cr-EDTA solution were mixed with $640 \mathrm{ml}$ of distilled water before infusion. Ytterbium chloride $\left(\mathrm{YbCl}_{3} \cdot 6 \mathrm{H}_{2} \mathrm{O}\right)$ solution was prepared by dissolving $24 \mathrm{~g}$ in 5 litres of distilled water.

The analysis of $\mathrm{Cr}$ and $\mathrm{Yb}$ was carried out as described by de Vega \& Poppi ${ }^{(18)}$. Standards were made by spiking blank duodenal samples with different amounts of $\mathrm{Cr}$ and $\mathrm{Yb}$ solutions of known concentrations and treating them in the same way as the experimental samples. Marker concentrations were determined by inductively coupled plasma atomic emission spectroscopy.

Paper pellets containing $\mathrm{C}_{32}$ and $\mathrm{C}_{36}$ were prepared following the technique described by Keli et al. ${ }^{(19)}$. About $5 \%$ of the pellets were sampled and analysed for alkane concentration, as described by Valiente et $a l .{ }^{(20)}$.
Ground samples of lucerne, ryegrass, refusals, LAB, whole duodenal digesta, solid phase of duodenal digesta and faeces were analysed for $n$-alkane concentrations following the procedures described by Keli et al. ${ }^{(19)}$ for analysis of faecal samples.

The isotope abundance $\left({ }^{15} \mathrm{~N}\right)$ of microbial $\mathrm{N}$ (LAB and $\mathrm{SAB}$ fractions) and non- $\mathrm{NH}_{3} \mathrm{~N}$ (NAN) in the solid and liquid phases of duodenal samples was determined by MS (VG PRISM II; IRMS) connected in series to a Dumas-style $\mathrm{N}$ analyser (EA 1108 Carlo Erba) by the Interdepartmental Service for Research of the Universidad Autónoma de Madrid (SidI).

\section{Other analytical procedures}

The OM in feeds, refusals, faeces, rumen contents, whole duodenal digesta, solid phase of duodenal digesta and bacterial fractions was determined by ashing at $550^{\circ} \mathrm{C}$ for $8 \mathrm{~h}$. Total $\mathrm{N}$ was determined following the Kjeldahl method using Se as a catalyst and a 2300 Kjeltec Analyzer Unit (Foss Tecator). The NDF in feeds, refusals, rumen contents, whole duodenal digesta, solid phase of duodenal digesta and faeces was measured with an ANKOM 220 Fiber Analyser (Ankom Technology) on dried samples $\left(60^{\circ} \mathrm{C}\right.$ for $\left.48 \mathrm{~h}\right)$, as described by Mertens ${ }^{(21)}$. The ADF and ADL in feeds were measured as described by Association of Official Analytical Chemists ${ }^{(22)}$ (Association of Official Analytical Chemists Official Method 973.18) and Robertson \& Van Soest ${ }^{(23)}$ for ADF and ADL, respectively. Both NDF and ADF were expressed as ash-free residues.

Concentration of VFA in rumen fluid was determined by GC following the method described by Jouany ${ }^{(24)}$. Deproteinised samples were centrifuged at $1800 \mathrm{~g}$ for $10 \mathrm{~min}$, using 4-methylvaleric acid as an internal standard.

The $\mathrm{NH}_{3}$ concentration in rumen fluid was determined by the colorimetric method developed by Chaney \& Marbach ${ }^{(25)}$.

The NAN in freeze-dried samples of whole digesta and the solid phase of the duodenal digesta was also analysed by the Kjeldahl method after evaporation of $\mathrm{NH}_{3}$ following $1 \mathrm{M}-\mathrm{NaOH}$ addition. Samples were subsequently dried at $60^{\circ} \mathrm{C}$ for $48 \mathrm{~h}$.

\section{Calculation procedures}

Degradation parameters of DM, CP and NDF of lucerne and ryegrass during rumen incubation were calculated following the model proposed by $\varnothing$ rskov \& McDonald ${ }^{(26)}$, and using the non-linear regression procedure (PROC NLIN) of the SAS statistical package (version 8.1; SAS Institute).

Duodenal flow of DM and its fractions (including $n$-alkanes) was estimated from the concentration of $\mathrm{Cr}$ and $\mathrm{Yb}$ in the whole duodenal digesta and its solid fraction, following the procedures described by Faichney ${ }^{(27)}$.

Faecal recovery of individual $n$-alkanes was calculated as the proportion of $n$-alkane consumed in the diet, which was excreted in the faeces. The concentration of a determined $n$-alkane in the ingesta was calculated as:

$$
C_{\mathrm{I}_{i}}=\frac{\left(\mathrm{DMO}_{\mathrm{L}} \times C_{\mathrm{L}_{i}}+\mathrm{DMO}_{\mathrm{RG}} \times C_{\mathrm{RG}_{i}}\right)-\left(\mathrm{DMR} \times C_{\mathrm{R}_{i}}\right)}{\mathrm{DMO}_{\mathrm{L}}+\mathrm{DMO}_{\mathrm{RG}}-\mathrm{DMR}},
$$


where $\mathrm{DMO}_{\mathrm{L}}$ and $\mathrm{DMO}_{\mathrm{RG}}$ are the amounts of lucerne and ryegrass (DM) offered, $C_{\mathrm{L} i}$ and $C_{\mathrm{RG} i}$ their concentrations in alkane $i$ and DMR and $C_{\mathrm{R} i}$ the amount of DM refused and its concentration in alkane $i$.

Duodenal recovery (DR) of $n$-alkanes was estimated as:

$$
\mathrm{DR}_{i}=\frac{C_{\mathrm{TD}_{i}} \times F_{\mathrm{DM}}}{D_{i}+\left(I \times C_{\mathrm{I}_{i}}\right)}
$$

where $C_{\mathrm{TD} i}$ represents the concentration of alkane $i$ in the DM of duodenal true digesta, $F_{\mathrm{DM}}$ the duodenal flow of DM, $D_{i}$ the amount of dosed alkane (if applicable), $I$ the DM intake (DMI) and $C_{\mathrm{I} i}$ the concentration of the alkane in the ingesta.

The diet composition was estimated by minimisation of the sum of the squared discrepancies between the measured faecal proportions of individual alkanes (recovery-corrected and expressed relative to the total faecal alkane; $R$ ) and diet alkane proportions (of the total alkane) calculated from alkane profiles of dietary components $(E)$, as follows ${ }^{(28)}$ :

$$
\sum[R-E]_{\text {alk: } 1 \ldots n}^{2}=\sum\left[\frac{H_{i}}{H_{\mathrm{t}}}-\frac{x A_{i}+y B_{i}}{x A_{\mathrm{t}}+y B_{\mathrm{t}}}\right]_{\mathrm{alk}: 1 \ldots n}^{2},
$$

where $x$ and $y(1-x)$ represent the proportions of components $\mathrm{A}$ and $\mathrm{B}$ in the diet; $H_{i}, A_{i}$ and $B_{i}$ the concentrations of alkane $i$ in faeces (recovery-corrected) and components A and $\mathrm{B}$; and $H_{t}, A_{t}$ and $B_{t}$ total alkane concentrations. The 'Solver' routine of the 'Excel' program (Microsoft) was used without non-negative restrictions ${ }^{(28)}$. Although all odd-chain alkanes were used in the first instance, the results presented in the present experiment only took account of the concentrations of $\mathrm{C}_{31}$ and $\mathrm{C}_{33}$, as those were the hydrocarbons that gave the best estimates, probably because they were found in higher concentrations in sheep faeces. The recovery correction factor of each alkane was estimated as the average from all animals for the balance trial faecal sampling.

The intake was calculated from the pair of alkanes $C_{31}$ (naturally present in the diet) and $\mathrm{C}_{32}$ (dosed) as follows ${ }^{(6)}$ :

$$
I=\frac{D_{32}}{\left(F_{32} / F_{31}\right) \times I_{31}-I_{32}},
$$

where $I$ is daily DMI $(\mathrm{kg}) ; D_{32}$ is amount of $C_{32}$ dosed daily (mg); and $F_{31}, F_{32}, I_{31}$ and $I_{32}$ are the concentrations of $C_{31}$ and $\mathrm{C}_{32}$ in faeces and intake, respectively ( $\left.\mathrm{mg} / \mathrm{kg} \mathrm{DM}\right)$. The two latter were estimated from the calculated proportions of lucerne and ryegrass in the diet.

Digestibility of DM (DMD) was calculated using $\mathrm{C}_{31}$ as the internal marker as follows:

$$
\mathrm{DMD}=1-\frac{I_{31} \times \mathrm{FR}_{31}}{F_{31}},
$$

where $\mathrm{FR}_{31}$ represents the faecal recovery of the alkane, calculated as shown earlier.

Isotopic enrichment was calculated in all cases by difference in the tracer:tracee ratio $\left({ }^{15} \mathrm{~N}:{ }^{14} \mathrm{~N}\right)$ of labelled and background samples. Then, microbial contribution (Nmic) to duodenal flow of NAN (NAN $N_{\text {digesta }}$ ) was calculated according to the following equation:

$$
\mathrm{Nmic} / \mathrm{NAN}_{\text {digesta }}=E_{\text {digesta }} / E_{\text {bacteria }},
$$

where $E_{\text {digesta }}$ is the ${ }^{15} \mathrm{~N}$ enrichment of NAN in true digesta, and $E_{\text {bacteria }}$ that of bacterial N, using LAB or SAB fraction as reference bacterial sample.

The efficiency of microbial protein synthesis (MPS) was calculated according to the equation:

$$
\text { Efficiency of MPS }=\frac{F_{\mathrm{Nmic}}}{\mathrm{OMADR}},
$$

where $F_{\mathrm{Nmic}}$ is the microbial $\mathrm{N}$ flow (calculated as the flow of NAN multiplied per Nmic (mic-N/NAN digesta $)$ ) and OMADR is the OM apparently digested in the rumen, calculated as the difference between OM intake (OMI) and OM flow at the duodenum. OM truly digested in rumen (OMTDR) was calculated as the sum of OMADR and the microbial OM flow, assuming a ratio $\mathrm{N}: \mathrm{OM}$ in both $\mathrm{SAB}$ and LAB of $\left.0 \cdot 10^{(29)}\right)$.

The proportion of $n$-alkanes of bacterial origin ( $n$-alkanes bacteria ) reaching the duodenum (only LAB fraction) was calculated as

$$
n \text {-alkanes }_{\text {bacteria }}=\frac{\left(\frac{C_{i}}{N}\right)_{\mathrm{LAB}} \times F_{\mathrm{NmicLAB}}}{F_{i}},
$$

where $C_{\mathrm{i}}$ and $N$ are the concentrations of alkane $i(\mathrm{mg} / \mathrm{kg} \mathrm{DM})$ and $\mathrm{N}(\mathrm{g} / \mathrm{kg} \mathrm{DM})$ in LAB; $F_{\text {NmicLAB }}$ is the duodenal flow of microbial $\mathrm{N}$ estimated from $\mathrm{LAB}(\mathrm{g} / \mathrm{d})$; and $F_{i}$ the flow of alkane $i$ reaching the duodenum $(\mathrm{mg} / \mathrm{d})$.

The rate of disappearance of DM, OM, CP and NDF from the rumen $(K)$ was calculated from hourly known intake of each fraction $(F)$ and the corresponding rumen pool $(V)$ as

$$
K=\frac{F}{V} .
$$

\section{Statistical analysis}

All the results, except rumen degradation parameters, were subjected to ANOVA using the SAS statistical package (version 8.01; SAS Institute), according to the model:

$$
y=\mu+D_{i}+A_{j}+P_{k}+\varepsilon_{l(i j k)},
$$

where $D_{i}(3 \mathrm{df})$ represents the diet effect, $A_{j}(3 \mathrm{df})$ the animal effect, $P_{k}(3 \mathrm{df})$ the effect due to the different periods of the latin square and $\varepsilon_{l(i j k)}(6 \mathrm{df})$ the experimental error.

For rumen degradation, the model used was:

$$
y=\mu+D_{i}+A_{j}+P_{k}+H_{l}+\mathrm{DH}_{i l}+\varepsilon_{m(i j k l)},
$$

where $D_{i}, A_{j}$ and $P_{k}$ were as given earlier, $H_{l}$ represented the effect due to the hay incubated (lucerne or ryegrass, $1 \mathrm{df}$ ), $\mathrm{DH}_{i l}$ the interaction between diet and hay type $(3 \mathrm{df})$ and $\varepsilon_{m(i j k l)}(18 \mathrm{df})$ the experimental error. The diet effect was tested against $P \times A(D)_{k j(i)}$.

For comparisons between observed and n-alkanes' estimated values of intake and digestibility, the following split-plot model was used:

$$
y=\mu+D_{i}+A_{j}+P_{k}+\mathrm{AP}_{j k}+M_{l}+\mathrm{DM}_{i l}+\varepsilon_{m(i j k l)},
$$

where $D_{i}, A_{j}$ and $P_{k}$ were tested against the interaction $\mathrm{AP}_{j k}$ ( $6 \mathrm{df}$ ), whereas the method ( $M_{l}$; observed or $n$-alkane estimated; $1 \mathrm{df}$ ) and the interaction between diet and 
method $\left(\mathrm{DM}_{i l} ; 3 \mathrm{df}\right)$ were tested against the experimental error $\left(\varepsilon_{m(i j k l)} ; 12 \mathrm{df}\right)$.

The actual and alkane-estimated values of diet composition, intake and digestibility were further compared by means of paired $t$ test for each diet type.

The PROC MIXED procedure was used for the aforementioned analysis, following the recommendations provided by Kaps \& Lamberson ${ }^{(30)}$. As sheep for fistulation were chosen according to their weight and strength, animal was not modelled as a random effect. Where an effect was significant, polynomial contrasts were applied to check for linear, quadratic or cubic response to lucerne proportion in the diet. As the cubic component of the regression was not significant in any case, it will not be included in the tables. Differences between treatment means were evaluated by the Scheffe test, due to the appearance of missing values. The standard errors of means given in tables are weighted for the same reason. Comparison of rumen bacterial fractions (LAB and $\mathrm{SAB}$ ) was made by a paired $t$ test.

Relationships between digesta flows and intake and between the various components of digesta flow, were examined using either simple or multiple regressions. When both dependent and independent variables were flows, the regression was constrained through the origin. The PROC REG procedure of the SAS statistical package was used for this purpose.

\section{Results}

Intake, digestibility, duodenal flow and microbial protein synthesis

Table 2 shows the intake and the rumen and total tract digestibility of DM, OM and NDF together with total tract digestibility of $\mathrm{CP}$. The duodenal flow of these fractions and that of microbial $\mathrm{N}$ (estimated from the LAB and SAB fractions as reference sample) are also given.

Intake of DM and its fractions (except NDF) was affected by $\operatorname{diet}(P<0.05)$, with values linearly decreasing as ryegrass proportion in the diet increased. However, digestibility (either in the rumen or in the whole tract) was not affected by the different combinations of legume and grass hays, with the exception of total tract $\mathrm{CP}$ values, which decreased $(P<0.01)$ as the proportion of ryegrass in the diet increased, lowering the $\mathrm{N}$ content of the diets. The OM truly digested in the

Table 2. Intake, digestibility, duodenal flow, microbial contribution to duodenal flow of nitrogen and efficiency of synthesis of microbial protein in sheep fed different proportions of lucerne and ryegrass (Lolium rigidum) hays (D)

\begin{tabular}{|c|c|c|c|c|c|c|c|}
\hline & \multirow[b]{2}{*}{ D1 } & \multirow[b]{2}{*}{ D2 } & \multirow[b]{2}{*}{ D3 } & \multirow[b]{2}{*}{ D4 } & \multirow[b]{2}{*}{ SEM } & \multicolumn{2}{|c|}{ Significance } \\
\hline & & & & & & Linear & Quadratic \\
\hline \multicolumn{8}{|l|}{ Intake $(g / d)$} \\
\hline DMI & 848 & 774 & 658 & 560 & $52 \cdot 1$ & 0.017 & 0.836 \\
\hline $\mathrm{OMI}$ & 766 & 705 & 601 & 517 & 48.5 & 0.021 & 0.832 \\
\hline $\mathrm{NI}$ & $21 \cdot 1$ & 13.9 & 8.2 & 3.6 & 1.36 & 0.001 & 0.425 \\
\hline NDFI & 392 & 394 & 359 & 327 & $27 \cdot 2$ & 0.148 & 0.591 \\
\hline \multicolumn{8}{|l|}{ Digestibility (\%) } \\
\hline DMADR & 44.4 & $45 \cdot 2$ & 38.4 & $37 \cdot 8$ & 6.04 & 0.403 & 0.915 \\
\hline DMAD & 63.0 & 63.2 & 63.3 & $61 \cdot 2$ & 1.40 & 0.464 & 0.498 \\
\hline OMADR & 51.0 & $55 \cdot 1$ & 49.5 & $50 \cdot 1$ & 3.70 & 0.658 & 0.682 \\
\hline OMAD & $65 \cdot 3$ & $65 \cdot 8$ & 65.5 & 63.0 & 1.53 & 0.389 & 0.414 \\
\hline OMTDR-SAB & $44 \cdot 2$ & $44 \cdot 3$ & $35 \cdot 9$ & $29 \cdot 7$ & $2 \cdot 46$ & 0.019 & 0.323 \\
\hline OMTDR-LAB & 43.2 & $42 \cdot 9$ & $35 \cdot 8$ & 29.4 & $2 \cdot 14$ & 0.009 & 0.251 \\
\hline CPAD & 74.5 & $66 \cdot 2$ & $55 \cdot 3$ & $19 \cdot 7$ & $2 \cdot 50$ & 0.001 & 0.007 \\
\hline NDFADR & 53.7 & 55.6 & 58.6 & 58.6 & $3 \cdot 16$ & 0.195 & 0.988 \\
\hline NDFAD & 58.5 & $61 \cdot 8$ & 63.0 & $58 \cdot 8$ & 1.65 & 0.810 & 0.102 \\
\hline \multicolumn{8}{|c|}{ Duodenal flow $(\mathrm{g} / \mathrm{d})$} \\
\hline DM & 466 & 425 & 391 & 353 & 63.9 & 0.284 & 0.981 \\
\hline OM & 372 & 318 & 290 & 254 & 41.4 & 0.124 & 0.854 \\
\hline NDF & 183 & 175 & 141 & 129 & $21 \cdot 2$ & 0.123 & 0.927 \\
\hline NAN & $9 \cdot 10$ & 6.92 & $6 \cdot 83$ & $5 \cdot 30$ & 0.965 & 0.066 & 0.772 \\
\hline NAN/NI & 0.44 & 0.53 & 0.88 & 1.28 & 0.089 & 0.002 & 0.173 \\
\hline Nmic-SAB & 4.81 & 4.32 & 4.83 & $3 \cdot 12$ & 0.411 & 0.092 & 0.266 \\
\hline Nmic-LAB & 3.75 & 4.24 & 4.67 & 3.09 & 0.487 & 0.541 & 0.121 \\
\hline \multicolumn{8}{|l|}{ Nmic/NAN (\%) } \\
\hline SAB & 53.5 & 74.5 & $70 \cdot 8$ & $64 \cdot 4$ & $2 \cdot 70$ & 0.099 & 0.019 \\
\hline LAB & $41 \cdot 7$ & $60 \cdot 8$ & 68.4 & 63.6 & $2 \cdot 40$ & 0.003 & 0.010 \\
\hline \multicolumn{8}{|c|}{ Efficiency of microbial protein synthesis (g Nmic/kg OMTDR) } \\
\hline SAB & 11.5 & 9.4 & $15 \cdot 0$ & 10.5 & 1.26 & 0.672 & 0.449 \\
\hline $\mathrm{LAB}$ & 9.2 & $10 \cdot 1$ & 14.7 & $10 \cdot 6$ & 1.63 & 0.314 & 0.238 \\
\hline
\end{tabular}

D1, $100 \%$ lucerne; D2, $67 \%$ lucerne and 33\% ryegrass; D3, 33\% lucerne and 67\% ryegrass; D4, 100\% ryegrass; DMI, DM intake; OMI, organic matter intake; NI, $\mathrm{N}$ intake; NDFI, neutral-detergent fibre intake; DMADR, DM apparently digested in rumen; DMAD, DM apparently digested in faeces; OMADR, organic matter apparently digested in rumen; OMAD, organic matter apparently digested in faeces; OMTDR-SAB, organic matter truly digested in rumen, estimated from the solid-adherent bacteria as reference sample; OMTDR-LAB, organic matter truly digested in rumen, estimated from the liquid-adherent bacteria as reference sample; CPAD, crude protein apparently digested in faeces; NDFADR, NDF apparently digested in rumen; NDFAD, NDF apparently digested in faeces; DM, duodenal flow of DM; OM, duodenal flow of organic matter; $\mathrm{NAN}$, duodenal flow of non- $\mathrm{NH}_{3} \mathrm{~N}$; Nmic-SAB, duodenal flow of microbial $\mathrm{N}$ estimated from the solidadherent bacteria as reference sample; Nmic-LAB, duodenal flow of microbial $\mathrm{N}$ estimated from the liquid-adherent bacteria as reference sample. 
rumen also decreased linearly with the proportion of ryegrass in the diet, regardless of whether it was estimated from SAB or $\mathrm{LAB}$ as reference sample. Rumen $\mathrm{CP}$ digestibility is not presented, as it was negative for diets containing ryegrass.

Duodenal flows of DM, OM, NDF, NAN and Nmic, estimated from $S A B$ and $L A B$, were not affected by diet, despite the fact that differences between treatments were important in some cases. Following differences in intake, duodenal flows decreased, although not significantly, with increasing proportions of ryegrass in the diet. This led to a linear increase of the NAN:N intake ratio for increasing proportions of ryegrass $(P=0 \cdot 002)$. The microbial $\mathrm{N}$ contribution to duodenal NAN was quadratic across diets $(P<0 \cdot 05)$, with the wholelucerne diet showing the lowest values for both estimates ( $\mathrm{SAB}$ or $\mathrm{LAB}$ ). On average, this contribution was $0 \cdot 12$ higher when estimated from $\mathrm{SAB}$ as reference sample than from LAB $(P=0.006)$. Efficiency of MPS estimated from either SAB or LAB was not affected by diet $(P>0 \cdot 10)$, although diet D3 showed values $43 \%(\mathrm{SAB})-47 \%$ (LAB) higher than the average of D1, D2 and D4.

The regression equations relating the flows of digesta or digesta components to intake, and relating the components of digesta flow are given in Table 3. As expected, flows of DM and OM at the duodenum were closely related to their respective intakes. Similarly, the relationships between NAN flow and DMI, OMI, NI or DOM intake (DOMI) were all highly significant $(P<0 \cdot 01)$. Although significant $(P=0.028)$, the correlation between NAN flow to the small intestine and OMADR was low ( $r$ 0.584). Substitution of OMADR by OMTDR estimated from either SAB or LAB improved the correlation coefficient only slightly, but did not change the relationship substantially. NI provided the highest correlation with NAN flow to the small intestine $(r$ 0.782), but this was not improved by including DOMI in the model (in fact, all coefficients became not significant). The inclusion of
OMADR together with NI in the regression increased the correlation coefficient only marginally ( $r$ 0.784), although in this case both independent variables were significant. However, the inclusion of OMTDR together with NI in the relationship did not improve the model, as the second independent variable was not significant, regardless of whether it was estimated from SAB or LAB (equations not presented in the table). The NAN flow to the duodenum was also highly correlated with OM flow ( $r$ 0.975), whereas Nmic flow estimated from SAB showed significant $(P<0.05)$ but low correlations with either OMI $(r 0.642)$ or NI $(r 0.603)$. The flow of Nmic estimated from LAB was not correlated $(P>0 \cdot 10)$ with either OMI or NI, hence these relationships have not been included in Table 3. The flow of microbial protein estimated from either SAB or LAB was highly correlated $(P<0.0001$ and $r>0.95$ ) with OM and NAN flow. However, the efficiency of synthesis of microbial protein, estimated from SAB or LAB, was not correlated $(P>0 \cdot 10)$ with OMI, DOMI or NI.

\section{Rumen fermentation and degradation, rumen fill and kinetics of disappearance from the rumen}

Rumen $\mathrm{pH}$ and concentrations of VFA and $\mathrm{NH}_{3}$ are given in Table 4 and rumen degradation parameters are shown in Table 5.

Rumen $\mathrm{pH}$ was close to neutrality with all four treatments, with no significant differences $(P>0 \cdot 10)$ between them, whereas $\mathrm{NH}_{3}$ concentration linearly decreased $(P<0 \cdot 001)$ with increasing proportions of ryegrass in the diet. The VFA concentration was not affected by diet $(P>0 \cdot 10)$, although the molar proportions of butyric acid linearly decreased $(P=0.036)$ with increasing proportions of ryegrass in the diet. Acetic and propionic molar proportions, and the ratio of acetic:propionic acid were not affected by diet either $(P>0 \cdot 10)$.

Table 3. Regression equations relating digesta flows and intake or relating the components of digesta flow, in sheep fed different proportions of lucerne and ryegrass (Lolium rigidum) hays*

\begin{tabular}{lr}
\hline Regressions & $r^{2}$ \\
\hline DM flow $=0.44(0.084 ; P=0.0002) \mathrm{DMI}+92.2(61.00 ; P=0.157)$ & 0.699 \\
OM flow $=0.38(0.085 ; P=0.0007) \mathrm{OMI}+60.4(55.95 ; P=0.302)$ & 0.630 \\
NAN flow $=0.0091(0.00232 ; P=0.002) \mathrm{DMI}+0.69(1.689 ; P=0.690)$ & 0.563 \\
NAN flow $=0.0101(0.00263 ; P=0.002) \mathrm{OMI}+0.60(1.738 ; P=0.737)$ & 0.555 \\
NAN flow $=0.25(0.058 ; P=0.001) \mathrm{NI}+4.1(0.80 ; P=0.0002)$ & 0.612 \\
NAN flow $=0.0155(0.00370 ; P=0.001)$ DOMI $+0.65(1.599 ; P=0.692)$ & 0.593 \\
NAN flow $=0.15(0.098 ; P=0.165) \mathrm{NI}+0.0079(0.00618 ; P=0.227)$ DOMI $+2.1(1.79 ; P=0.276)$ & 0.661 \\
NAN flow $=0.0117(0.00468 ; P=0.028)$ OMADR $+3.2(1.66 ; P=0.078)$ & 0.341 \\
NAN flow $=0.23(0.082 ; P=0.017) \mathrm{NI}+0.0019(0.00511 ; P=0.017)$ OMADR $+3.7(1.33 ; P=0.017)$ & 0.615 \\
NAN flow $=0.0112(0.00437 ; P=0.026)$ OMTDR 3 SAB $+2.7(1.70 ; P=0.139)$ & 0.376 \\
NAN flow $=0.0119(0.00434 ; P=0.018)$ OMTDR 2 LAB $+2.6(1.70 ; P=0.148)$ & 0.387 \\
NAN flow $=0.023(0.0015 ; P<0.0001)$ OM flow & 0.951 \\
Nmic (SAB) flow $=0.0042(0.00150 ; P=0.018)$ OMI $+1.65(0.981 ; P=0.121)$ & 0.412 \\
Nmic (SAB) flow $=0.0908(0.03619 ; P=0.029)$ NI $+3.2(0.50 ; P<0.0001)$ & 0.364 \\
Nmic (SAB) flow $=0.0136(0.00099 ; P<0.0001)$ OM flow & 0.939 \\
Nmic (LAB) flow $=0.0123(0.00104 ; P<0.0001)$ OM flow & 0.916 \\
Nmic (SAB) flow $=0.60(0.027 ; P<0.0001)$ NAN flow & 0.976 \\
Nmic (LAB) flow $=0.53(0.034 ; P<0.0001)$ NAN flow & 0.951
\end{tabular}

DMI, DM intake, OM, organic matter, OMI, OM intake, NAN, non- $\mathrm{NH}_{3} \mathrm{~N}, \mathrm{NI}, \mathrm{N}$ intake, DOMI, digestible OM intake, OMADR, $\mathrm{OM}$ apparently digested in rumen, OMTDR $\mathrm{SAB}_{\mathrm{B}}$, OM truly digested in rumen estimated from solid-adherent bacteria, OMTDR $_{L A B}$, OM truly digested in rumen estimated from liquid-adherent bacteria, Nmic (SAB), microbial $N$ estimated from solid-adherent bacteria, Nmic (LAB), microbial $\mathrm{N}$ estimated from liquid-adherent bacteria.

* Standard errors and $P$ values of each coefficient are given within parentheses. 
Table 4. Rumen $\mathrm{pH}$ and concentrations of ammonia and volatile fatty acids (VFA) in sheep fed different proportions of lucerne and ryegrass (Lolium rigidum) hays (D)

\begin{tabular}{lccccrrr}
\hline & & & & & & & \multicolumn{2}{c}{ Significance } \\
\cline { 5 - 8 } & D1 & D2 & D3 & D4 & SEM & Linear & Quadratic \\
\hline $\mathrm{pH}$ & 6.98 & 6.95 & 6.91 & 6.78 & 0.11 & 0.291 & 0.716 \\
$\mathrm{NH}_{3}(\mathrm{mg} / \mathrm{l})$ & 315 & 219 & 159 & 35 & 15.98 & $<0.001$ & 0.458 \\
$\mathrm{VFA}(\mathrm{mmol} / \mathrm{l})$ & 111 & 75 & 73 & 68 & 8.29 & 0.104 & 0.184 \\
Molar proportions (\%) & & & & & & & \\
$\quad$ Acetic & 62.2 & 60.7 & 65.3 & 65.2 & 2.81 & 0.363 & 0.821 \\
$\quad$ Propionic & 19.5 & 20.9 & 20.3 & 23.9 & 1.34 & 0.120 & 0.478 \\
$\quad$ Butyric & 11.4 & 12.4 & 10.8 & 8.9 & 0.62 & 0.036 & 0.092 \\
Acetic/propionic & 3.3 & 2.9 & 3.3 & 2.8 & 0.34 & 0.558 & 0.859 \\
\hline
\end{tabular}

D1, $100 \%$ lucerne; D2, $67 \%$ lucerne and 33\% ryegrass; D3, 33\% lucerne and 67\% ryegrass; D4, $100 \%$ ryegrass.

Table 5 shows the effect of ruminal environment (as determined by the proportions of lucerne and ryegrass in the diet) on DM, CP and NDF degradation kinetics of both forages. Neither potential degradability nor fractional rate of degradation of CP and NDF from lucerne and ryegrass were affected by the diet type $(P>0 \cdot 10)$. On the other hand, potential degradability of lucerne $\mathrm{CP}$ was higher than that of ryegrass $(P<0.001)$, whereas the opposite occurred for NDF $(P<0.001)$, although the fractional rate of degradation of this latter was higher for the legume $(P=0.005)$. For DM, there was a significant interaction between diet and forage incubated for both potential degradability $(P=0.017)$ and fractional rate of degradation $(P=0.002)$. As a result, the potential degradability of ryegrass was higher compared to lucerne for diets D1 and D2, and lower for D4, with no statistical differences between forages for D3.
Table 6 shows the rumen contents and the fractional rate of disappearance from the rumen of DM, OM, CP and NDF. None of the parameters (except $\mathrm{CP}$ fractional rate of disappearance; $P=0 \cdot 009)$ was affected by diet type, although there was a tendency for $\mathrm{CP}$ contents $(P=0 \cdot 062)$. Rumen contents of all fractions decreased as the proportion of ryegrass in the diet increased, even though not significantly.

\section{$\mathrm{n}$-Alkane recoveries}

Average concentrations of $n$-alkanes in ingesta, LAB, whole duodenal digesta and faeces are presented in Table 7. In general, concentration of $n$-alkanes was higher in faeces than in duodenal digesta, which in turn showed higher concentrations than LAB. Besides, the $n$-alkane profile of LAB, duodenal digesta and faeces was closely related to that of the diet

Table 5. DM, crude protein (CP) and neutral-detergent fibre (NDF) potential degradability and fractional rate of degradation of lucerne and ryegrass (Lolium rigidum) hays in sheep fed different proportions of both (D)

\begin{tabular}{|c|c|c|c|c|c|c|c|c|c|}
\hline & \multicolumn{4}{|c|}{$\mathrm{RE}$} & \multirow[b]{2}{*}{ SEM $^{*}$} & \multirow[b]{2}{*}{ SEM† } & \multicolumn{3}{|c|}{ Significance } \\
\hline & D1 & D2 & D3 & D4 & & & RE & Hay & RE $\times$ Hay \\
\hline \multicolumn{10}{|c|}{ DM } \\
\hline \multicolumn{10}{|c|}{ Potential degradability (\%) } \\
\hline Lucerne & $70 \cdot 4^{\mathrm{b}}$ & $69 \cdot 7^{\mathrm{b}}$ & $73 \cdot 2$ & $78 \cdot 2^{\mathrm{a}}$ & 3.96 & 4.47 & 0.874 & 0.074 & 0.017 \\
\hline Ryegrass & $79 \cdot 7^{\mathrm{a}}$ & $79.4^{\mathrm{a}}$ & $82 \cdot 3$ & $67 \cdot 0^{\mathrm{b}}$ & & & & & \\
\hline \multicolumn{10}{|c|}{ Fractional rate of degradation (per $h$ ) } \\
\hline Lucerne & $0.088^{a, B}$ & $0 \cdot 125^{\mathrm{a}, \mathrm{A}}$ & $0.124^{\mathrm{a}, \mathrm{A}}$ & $0.049^{\mathrm{C}}$ & 0.0061 & 0.0085 & 0.031 & $<0.001$ & 0.002 \\
\hline Ryegrass & $0.043^{b}$ & $0.054^{\mathrm{b}}$ & $0.040^{\mathrm{b}}$ & 0.059 & & & & & \\
\hline \multicolumn{10}{|c|}{$\mathrm{CP}$} \\
\hline \multicolumn{10}{|c|}{ Potential degradability (\%) } \\
\hline Lucerne & 88.4 & $87 \cdot 7$ & $88 \cdot 3$ & $88 \cdot 7$ & 1.36 & 1.61 & 0.583 & $<0.001$ & 0.591 \\
\hline Ryegrass & $58 \cdot 8$ & $64 \cdot 0$ & $62 \cdot 1$ & 64.5 & & & & & \\
\hline \multicolumn{10}{|c|}{ Fractional rate of degradation (per h) } \\
\hline Lucerne & 0.092 & $0 \cdot 110$ & 0.084 & 0.076 & 0.0180 & 0.0521 & 0.352 & 0.331 & 0.460 \\
\hline Ryegrass & 0.122 & 0.048 & 0.028 & 0.076 & & & & & \\
\hline \multicolumn{10}{|c|}{ NDF } \\
\hline \multicolumn{10}{|c|}{ Potential degradability (\%) } \\
\hline Lucerne & $47 \cdot 7$ & $47 \cdot 2$ & $49 \cdot 3$ & $48 \cdot 0$ & 1.63 & $2 \cdot 28$ & 0.975 & $<0.001$ & 0.671 \\
\hline Ryegrass & $78 \cdot 3$ & $80 \cdot 2$ & $76 \cdot 8$ & $77 \cdot 4$ & & & & & \\
\hline \multicolumn{10}{|c|}{ Fractional rate of degradation (per h) } \\
\hline Lucerne & 0.074 & 0.074 & 0.069 & 0.063 & 0.0132 & 0.0163 & 0.953 & 0.005 & 0.959 \\
\hline Ryegrass & 0.034 & 0.032 & 0.041 & 0.028 & & & & & \\
\hline
\end{tabular}

$\mathrm{RE}$, rumen environment; D1, $100 \%$ lucerne; D2, $67 \%$ lucerne and 33\% ryegrass; D3, $33 \%$ lucerne and $67 \%$ ryegrass; D4, $100 \%$ ryegrass.

a,b Mean values within a column with unlike superscript letters were significantly different $(P=0.05)$.

$\mathrm{A}, \mathrm{B}, \mathrm{C}$ Mean values within a row with unlike superscript letters were significantly different $(P=0.05)$.

* SEM for comparisons between rumen environments.

†SEM for comparisons between hays, between hays within each rumen environment and between rumen environments within each hay. 
Table 6. Rumen contents, and fractional rate of disappearance from the rumen of DM, organic matter (OM), crude protein (CP) and neutral-detergent fibre (NDF) in sheep fed different proportions of lucerne and ryegrass (Lolium rigidum) hays (D)

\begin{tabular}{|c|c|c|c|c|c|c|c|}
\hline & \multirow[b]{2}{*}{ D1 } & \multirow[b]{2}{*}{ D2 } & \multirow[b]{2}{*}{ D3 } & \multirow[b]{2}{*}{ D4 } & \multirow[b]{2}{*}{ SEM } & \multicolumn{2}{|c|}{ Significance } \\
\hline & & & & & & Linear & Quadratic \\
\hline \multicolumn{8}{|c|}{ Rumen contents (g) } \\
\hline DM & 529 & 491 & 354 & 390 & $79 \cdot 2$ & $0 \cdot 212$ & 0.683 \\
\hline OM & 454 & 422 & 300 & 335 & $66 \cdot 2$ & 0.201 & 0.667 \\
\hline $\mathrm{CP}$ & 82 & 73 & 55 & 44 & $10 \cdot 8$ & 0.062 & 0.970 \\
\hline NDF & 329 & 297 & 201 & 245 & $51 \cdot 9$ & 0.229 & 0.536 \\
\hline \multicolumn{8}{|c|}{ Fractional rate of disappearance from the rumen (per $h$ ) } \\
\hline DM & 0.069 & 0.068 & 0.078 & 0.062 & 0.0093 & 0.795 & 0.489 \\
\hline OM & 0.073 & 0.072 & 0.084 & 0.067 & 0.0095 & 0.901 & 0.476 \\
\hline $\mathrm{CP}$ & 0.068 & 0.050 & 0.041 & 0.025 & 0.0060 & 0.009 & 0.920 \\
\hline NDF & 0.053 & 0.058 & 0.075 & 0.059 & 0.0084 & 0.427 & 0.295 \\
\hline
\end{tabular}

D1, $100 \%$ lucerne; D2, $67 \%$ lucerne and 33\% ryegrass; D3, 33\% lucerne and 67\% ryegrass; D4, $100 \%$ ryegrass.

consumed. An unexpected result was the significant amount of $n$-alkanes found in bacteria, in concentrations high enough to be detected in all cases. Regardless of the type of sample, odd-chain alkanes represented 94-97\% of total alkanes, excluding $\mathrm{C}_{22}$ and $\mathrm{C}_{34}$ (internal standards) and $\mathrm{C}_{32}$ and $\mathrm{C}_{36}$ (dosed alkanes).

Duodenal recoveries of the $n$-alkanes with concentrations in the intake higher than $15 \mathrm{mg} / \mathrm{kg} \mathrm{DM}$ (for all diets) are given in Table 8. Dosed alkanes $\left(\mathrm{C}_{32}\right.$ and $\left.\mathrm{C}_{36}\right)$ are also included. Recoveries were not affected by diet, although there was a tendency for $\mathrm{C}_{33}$ to linearly increase with the proportion of ryegrass in the diet $(P=0.055)$. In some cases, differences were important in numerical terms. Alkanes with higher dietary concentrations (including dosed $\mathrm{C}_{32}$ and $\mathrm{C}_{36}$ ) had average duodenal recoveries of 107 (SEM 10.8) \% $\left(\mathrm{C}_{27}\right)$, 112 (SEM 16.7)\% ( $\left.\mathrm{C}_{29}\right), 107$ (SEM 14.5)\% ( $\left.\mathrm{C}_{31}\right), 101$ (SEM $5 \cdot 2) \%\left(\mathrm{C}_{32}\right)$ and $94(\operatorname{sem} 6 \cdot 4) \%\left(\mathrm{C}_{36}\right)$.

The contribution of LAB alkanes to the duodenal flow of $n$-alkanes is shown in Table 9. Diet effect was highly significant $(P<0 \cdot 01)$ for $\mathrm{C}_{27}, \mathrm{C}_{29}, \mathrm{C}_{31}$ and $\mathrm{C}_{33}$, with higher microbial contribution ( $7.6 \%$ on average) for diets high in ryegrass (D3 and D4) than for those based on lucerne ( $4 \cdot 2 \%$ on average). The linear component of the regression of microbial alkane contribution on grass proportion in the diet was significant for all four of these hydrocarbons. Contribution of microbial $\mathrm{C}_{32}$ and $\mathrm{C}_{36}$ (dosed alkanes) to their duodenal flow was not affected by diet type ( $P=0.396$ for $\mathrm{C}_{32}$ and $P=0.057$ for $C_{36}$, respectively).

Faecal recovery of $n$-alkanes was on average much lower than duodenal recovery and decreased linearly as the proportion of ryegrass in the diet increased, except for $\mathrm{C}_{31}, \mathrm{C}_{32}$, $\mathrm{C}_{33}$ and $\mathrm{C}_{36}$ (Table 10). As expected, faecal recovery $(y)$ increased with chain length $(x) \quad(y=4.98 x-78.65$ $\left(r^{2} \quad 0.736 ; \quad P<0.0001\right)$ for a linear fitting, and $y=-0.252 x^{2}+19.94 x-296.88\left(r^{2} 0.766 ; P<0.0001\right)$ for a quadratic fitting). Animal variability was high in all cases, as shown by the associated standard errors of the means.

\section{Estimates of diet composition, intake and digestibility using the $\mathrm{n}$-alkane technique}

In Table 11 the mean values of diet composition, intake and digestibility estimated from $n$-alkanes are compared with those recorded when different proportions of lucerne and ryegrass were fed.

The accuracy of the $n$-alkanes technique for estimating diet composition was not affected by diet $(P=0.9727)$, with differences between observed and estimated values of small importance in absolute terms $(<5 \%$ in the worst case, that of animals fed $67 \%$ lucerne and $33 \%$ ryegrass). This was reflected in the absence of differences between observed and estimated values for any of the diets considered $(P>0.05)$ when a test of paired $t$ values was performed. Individual variability was important, as shown by the high SEM values.

Estimates of DMI were made taking into account faecal recoveries of $\mathrm{C}_{31}$ and $\mathrm{C}_{32}$, or ignoring them. As expected, values of estimated intake differed between diets, regardless of the method of estimation, the interaction being nonsignificant in all cases $(P>0.05)$. Ignoring faecal recoveries of $\mathrm{C}_{31}$ and $\mathrm{C}_{32}$ resulted in statistical differences between observed and estimated values, whereas taking into account of faecal recoveries led to an absence of statistical significance. A similar result arose when digestibility was estimated, assuming $100 \%$ faecal recovery of $\mathrm{C}_{31}$ or taking into account the actual value. As in the case of intake, diet had a significant effect on digestibility, regardless of the method employed for its estimation.

\section{Discussion}

Intake, digestibility, duodenal flow and microbial protein synthesis

As expected, daily intake of DM, OM and $\mathrm{N}$ decreased as ryegrass proportion in the diet increased, probably as a consequence of the interaction between chemical composition (mainly amount and type of fibre), rate of degradation and intake $^{(31,32)}$. However, NDF intake was not affected by diet type, and this agrees with the well-known role of cell wall as the main limiting factor of intake ${ }^{(33)}$. The amounts of digestible OM consumed (Table 2) were not enough to meet the animal's energy requirements (calculated according to Institut National de la Recherche Agronomique ${ }^{(34)}$ ), except for diet D1. The ryegrass used in the present experiment was L. rigidum, 
which is known to have low protein and high NDF contents (Table 1). In addition, the hay-making process led to the loss of a high amount of leaves, and then to an abnormally low CP content. Also, our animals were fistulated in both rumen and duodenum, and this might have had a negative effect on intake.

Despite differences of up to $62 \%$ in intake, apparent ruminal or whole-tract digestibility of DM, OM and NDF did not differ between diets. It has previously been observed ${ }^{(35)}$ that differences in intake when the rumen fill is not limiting do not have an effect on rate of passage (and hence on digestibility) but on rumen contents. This seems to be the case in the present experiment, as rumen fill reflected intake (although without significant differences between diets) with mostly negligible differences between treatments in disappearance kinetics (Table 6). In fact, NDF intake in animals fed D4 was on average $83 \%$ of that shown by animals fed D1, whereas NDF rumen fill was $74 \%$. It must be taken into account that the 'disappearance' rates shown in Table 6 include outflow of undegraded or partially degraded particles, and absorption of degraded products. It is then expected that passage rates would be much lower, allowing for retention times long enough to achieve close to full potential degradation of both lucerne and ryegrass.

Digestibility coefficients of $\mathrm{OM}$ in the rumen were close to those found by Cruickshank et al. ${ }^{(36)}$ in lambs grazing lucerne and ryegrass (L. perenne) paddocks, whereas NDF in our experiment showed a higher ruminal digestibility (0.93 of the NDF apparently digested in the whole tract) than that reported by those authors $(0.87$ for ryegrass and 0.78 for lucerne, respectively). This may relate to the lower quality of the forages used in the present experiment, especially for ryegrass, and the longer retention times here. The very low values of apparent $\mathrm{CP}$ digestibility in the whole tract with high-ryegrass diets were expected due to the low $\mathrm{N}$ content of these diets ${ }^{(37)}$.

Duodenal flows of DM, OM, NDF, NAN and Nmic, estimated from $\mathrm{SAB}$ or $\mathrm{LAB}$ were not significantly affected by diet, although in general there was a progressive decline following increasing proportions of ryegrass in the ration (and hence decreasing intake). By contrast, the proportion of ingested $\mathrm{N}$ recovered in the duodenum as NAN increased with the proportion of grass in the diet, being even higher than 1.0 for

Table 8. Duodenal recoveries (\% of intake) of $n$-alkanes in sheep fed different proportions of lucerne and ryegrass (Lolium rigidum) hays (D)*

\begin{tabular}{|c|c|c|c|c|c|c|c|}
\hline & \multirow[b]{2}{*}{ D1 } & \multirow[b]{2}{*}{ D2 } & \multirow[b]{2}{*}{ D3 } & \multirow[b]{2}{*}{ D4 } & \multirow[b]{2}{*}{ SEM } & \multicolumn{2}{|c|}{ Significance } \\
\hline & & & & & & Linear & Quadratic \\
\hline $\mathrm{C}_{27}$ & 99 & 106 & 112 & 110 & $10 \cdot 8$ & 0.480 & 0.715 \\
\hline $\mathrm{C}_{29}$ & 107 & 98 & 114 & 128 & $16 \cdot 7$ & 0.352 & 0.644 \\
\hline $\mathrm{C}_{31}$ & 101 & 94 & 110 & 124 & 14.5 & 0.283 & 0.638 \\
\hline $\mathrm{C}_{32}$ & 96 & 109 & 104 & 97 & $5 \cdot 2$ & 0.978 & 0.156 \\
\hline $\mathrm{C}_{33}$ & 108 & 128 & 143 & 170 & $15 \cdot 8$ & 0.055 & 0.862 \\
\hline $\mathrm{C}_{36}$ & 90 & 102 & 97 & 86 & 6.4 & 0.620 & 0.170 \\
\hline
\end{tabular}

D1, $100 \%$ lucerne; D2, $67 \%$ lucerne and $33 \%$ ryegrass; D3, 33\% lucerne and $67 \%$ ryegrass; D4, $100 \%$ ryegrass.

${ }^{*}$ Alkanes $\mathrm{C}_{22}$ and $\mathrm{C}_{34}$ were not included as they were used as internal standards. 
Table 9. Contribution of liquid-adherent bacteria-alkanes (\%) to the duodenal flow of $n$-alkanes in sheep fed different proportions of lucerne and ryegrass (Lolium rigidum) hays (D)*

\begin{tabular}{|c|c|c|c|c|c|c|c|}
\hline & \multirow[b]{2}{*}{ D1 } & \multirow[b]{2}{*}{ D2 } & \multirow[b]{2}{*}{ D3 } & \multirow[b]{2}{*}{ D4 } & \multirow[b]{2}{*}{ SEM } & \multicolumn{2}{|c|}{ Significance } \\
\hline & & & & & & Linear & Quadratic \\
\hline $\mathrm{C}_{25}$ & 6.47 & 5.06 & 8.96 & 8.37 & 0.860 & 0.122 & 0.695 \\
\hline $\mathrm{C}_{27}$ & 4.39 & $4 \cdot 27$ & $7 \cdot 85$ & $7 \cdot 12$ & 0.215 & 0.002 & 0.284 \\
\hline $\mathrm{C}_{28}$ & 4.23 & 3.48 & $7 \cdot 00$ & $5 \cdot 23$ & 0.550 & 0.154 & 0.423 \\
\hline $\mathrm{C}_{29}$ & 4.03 & 4.23 & 7.69 & $7 \cdot 89$ & 0.177 & $<0.001$ & 0.988 \\
\hline $\mathrm{C}_{30}$ & 3.44 & $2 \cdot 61$ & 5.08 & 4.09 & 0.353 & 0.096 & 0.856 \\
\hline $\mathrm{C}_{31}$ & $4 \cdot 16$ & $4 \cdot 19$ & 7.53 & $8 \cdot 11$ & 0.282 & 0.002 & 0.432 \\
\hline $\mathrm{C}_{32}$ & 1.71 & 5.53 & 5.42 & 5.59 & $2 \cdot 173$ & 0.396 & 0.541 \\
\hline $\mathrm{C}_{33}$ & $4 \cdot 13$ & 3.94 & 7.59 & $7 \cdot 38$ & 0.366 & 0.006 & 0.979 \\
\hline $\mathrm{C}_{36}$ & $2 \cdot 78$ & 1.90 & $5 \cdot 29$ & $5 \cdot 80$ & 0.246 & 0.057 & 0.266 \\
\hline
\end{tabular}

D1, 100\% lucerne; D2, $67 \%$ lucerne and 33\% ryegrass; D3, 33\% lucerne and $67 \%$ ryegrass; D4, $100 \%$ ryegrass.

${ }^{*}$ Alkanes $\mathrm{C}_{22}$ and $\mathrm{C}_{34}$ were not included as they were used as internal standards. Alkanes $\mathrm{C}_{23}, \mathrm{C}_{24}, \mathrm{C}_{26}$ and $\mathrm{C}_{35}$ were not included due to their very low concentrations.

diet D4. Urea recycling is known to play a significant role to this respect with diets low in $\mathrm{N}^{(37)}$, although digestive secretions and sloughing of the mucosa cells may also be involved $^{(12)}$, especially with diets high in NDF. No differences were found between duodenal flows of Nmic estimated from SAB or LAB (Table 2), except for diet D1 $(P=0 \cdot 017)$. Reasons for this latter discrepancy were not found. As previously reported $^{(36)}$, DOMI, a cruder estimate of energy available for microbial synthesis, was markedly higher correlated with NAN flow $(r$ 0.770) than OMADR $(r$ 0.584) or OMTDR ( $r$ 0.613 for SAB estimation and $r 0.622$ for LAB estimation). However, this might be expected given that Nmic is a variable part of duodenal NAN and that OMADR is a poor indicator of energy available in the rumen ${ }^{(36)}$. Nevertheless, OMTDR should be a better predictor, and the low correlation coefficients may indicate that the true values have equal or even more error than the apparent ones. Also, as discussed earlier $^{(36)}$, NAN flow was best predicted by NI, although in the present work the obtained relationship differed markedly and there was a larger variation (and then a lower $r$ ) than in the cited paper. Therefore, derived regressions between NI and NAN flow to the small intestine may yield erroneous predictions if applied to individual sets of experimental data.

Differences in rumen $\mathrm{NH}_{3}$ concentration between diets (Table 4) were not reflected in either rumen digestibility coefficients or the efficiency of MPS (Table 2), the latter being an important observation. Then, availability of $\mathrm{NH}_{3}$ was not limiting microbial growth even when its concentration in the rumen was below the suggested minimum value of $50 \mathrm{mg} / \mathrm{l}^{(38)}$ (diet D4). However, low concentrations of rumen $\mathrm{NH}_{3}$ may affect intake more than digestibility ${ }^{(39)}$, as seems to have been the case with this latter diet. The relationship between $\mathrm{NH}_{3}$ concentration in the rumen and the NAN:NI ratio was either linear (NAN:NI $=1.289-0.00274 \mathrm{NH}_{3} ; r^{2} 0.805$; $P<0.0001) \quad$ or $\quad$ quadratic $\quad(\mathrm{NAN}: \mathrm{NI}=1.438-0.00527$ $\left.\mathrm{NH}_{3}+0.00000689\left(\mathrm{NH}_{3}\right)^{2} ; r^{2} 0.887 ; P<0.0001\right)$, with full recoveries of $\mathrm{NI}$ as $\mathrm{NAN}$ at rumen $\mathrm{NH}_{3}$ concentrations below approximately $110 \mathrm{mg} / \mathrm{l}$. Combining data from Tables 1, 2 and 4 , the following relationship was obtained: $\mathrm{NH}_{3}(\mathrm{mg} / \mathrm{l})=0.724$ $(\mathrm{g} \mathrm{CP} / \mathrm{kg} \mathrm{DOM})+40.79\left(r^{2} 0.978 ; \quad P<0 \cdot 0001\right)$. From this equation, it was clear that the concentration of $\mathrm{CP} / \mathrm{kg} \mathrm{DOM}$ that would lead to an $\mathrm{NH}_{3}$ concentration in the rumen of $110 \mathrm{mg} / \mathrm{l}$ was approximately $100 \mathrm{~g}$, much lower than the $210 \mathrm{~g}$ figure proposed by Poppi \& McLennan ${ }^{(1)}$ for a complete net transfer of ingested protein to the duodenum. The likely different effective degradability of protein is the candidate to be blamed for the difference, and it might be speculated that reducing the rate of degradation of lucerne $\mathrm{CP}$ may help to achieve fully efficient utilisation of $\mathrm{N}$ in the rumen, without affecting microbial synthesis efficiency, when the legume is fed in combination with ryegrass.

Nmic contribution to duodenal flow of NAN increased with the proportion of grass hay in the diet. This result is in agreement with previous reports on the higher contribution of dietary $\mathrm{N}$ to duodenal NAN flow in animals fed forages low in NDF and high in $\mathrm{N}$ compared to those receiving high-fibre, low-N roughages ${ }^{(40)}$.

Overall, the efficiency of microbial synthesis was much lower than values reported for dried grass or legume hays ${ }^{(41)}$. Low efficiency is thought to result from a slow dilution rate ${ }^{(42)}$, a reduced intake ${ }^{(43)}$ or a slow fermentation in the rumen ${ }^{(44)}$. However, in the present experiment the relationships between fractional rates of disappearance of $\mathrm{DM}$ and its fractions from the rumen (Table 6) and Nmic estimated from either $\mathrm{SAB}$ or $\mathrm{LAB}$ were not significant $(P>0 \cdot 10$ and $r<0.50$ in all cases; equations not presented). A similar result has previously been observed for the liquid fraction of the rumen digesta by Dove \& Milne ${ }^{(29)}$. These authors already pointed out the difficulties of assigning the relative importance of intake and ruminal fermentation on efficiency of MPS.

\section{$\mathrm{n}$-Alkane concentration in intake, whole duodenal digesta, liquid-adherent bacteria and faeces}

Concentration of $n$-alkanes in duodenal digesta, LAB and faeces varied as a result of the different proportions of lucerne and ryegrass in the diet consumed (Table 7). The influence of

Table 10. Faecal recoveries (\% of intake) of $n$-alkanes in sheep fed different proportions of lucerne and ryegrass (Lolium rigidum) hays (D)*

\begin{tabular}{|c|c|c|c|c|c|c|c|}
\hline & \multirow[b]{2}{*}{ D1 } & \multirow[b]{2}{*}{ D2 } & \multirow[b]{2}{*}{ D3 } & \multirow[b]{2}{*}{ D4 } & \multirow[b]{2}{*}{ SEM } & \multicolumn{2}{|c|}{ Significance } \\
\hline & & & & & & Linear & Quadratic \\
\hline $\mathrm{C}_{23}$ & 44.5 & $40 \cdot 8$ & 30.4 & $18 \cdot 6$ & 2.08 & $<0.001$ & 0.145 \\
\hline $\mathrm{C}_{25}$ & 54.0 & $46 \cdot 7$ & $42 \cdot 0$ & $27 \cdot 4$ & 2.53 & 0.002 & 0.245 \\
\hline $\mathrm{C}_{26}$ & $52 \cdot 1$ & $56 \cdot 4$ & $45 \cdot 2$ & $20 \cdot 7$ & 5.83 & 0.019 & 0.083 \\
\hline $\mathrm{C}_{27}$ & $68 \cdot 8$ & $62 \cdot 7$ & $60 \cdot 3$ & $40 \cdot 5$ & $3 \cdot 63$ & 0.007 & $0 \cdot 155$ \\
\hline $\mathrm{C}_{28}$ & $77 \cdot 9$ & $68 \cdot 1$ & $62 \cdot 7$ & $42 \cdot 2$ & 4.85 & 0.008 & 0.364 \\
\hline $\mathrm{C}_{29}$ & $78 \cdot 6$ & 74.4 & 79.5 & $60 \cdot 0$ & $3 \cdot 73$ & 0.046 & 0.129 \\
\hline $\mathrm{C}_{30}$ & $78 \cdot 2$ & $73 \cdot 0$ & $74 \cdot 1$ & 53.9 & 4.42 & 0.027 & 0.192 \\
\hline $\mathrm{C}_{31}$ & $81 \cdot 8$ & 78.6 & 87.7 & $70 \cdot 3$ & 3.95 & 0.248 & 0.171 \\
\hline $\mathrm{C}_{32}$ & $92 \cdot 3$ & 89.0 & $96 \cdot 4$ & $75 \cdot 3$ & 3.48 & 0.057 & 0.075 \\
\hline $\mathrm{C}_{33}$ & 89.9 & 87.7 & 98.8 & 88.3 & 4.25 & 0.766 & 0.413 \\
\hline $\mathrm{C}_{35}$ & $80 \cdot 7$ & 84.7 & $89 \cdot 7$ & $116 \cdot 6$ & $7 \cdot 00$ & 0.027 & 0.205 \\
\hline $\mathrm{C}_{36}$ & 92.9 & $90 \cdot 8$ & 98.9 & $76 \cdot 3$ & $3 \cdot 38$ & 0.060 & 0.048 \\
\hline
\end{tabular}

D1, $100 \%$ lucerne; D2, $67 \%$ lucerne and 33\% ryegrass; D3, 33\% lucerne and $67 \%$ ryegrass; D4, $100 \%$ ryegrass.

${ }^{*}$ Alkanes $\mathrm{C}_{22}$ and $\mathrm{C}_{34}$ were not included as they were used as internal standards. Alkane $\mathrm{C}_{24}$ was not included due to missing data. 
Table 11. Observed and alkane-estimated values of diet composition, DM intake (DMI, g/d) and digestibility (DMD, \%) from sheep fed different proportions of lucerne and ryegrass (Lolium rigidum)

\begin{tabular}{|c|c|c|c|c|c|c|c|c|c|c|}
\hline & \multicolumn{4}{|c|}{ D (\% lucerne/ryegrass) } & \multirow[b]{2}{*}{ SEM } & \multicolumn{2}{|c|}{ M } & \multirow[b]{2}{*}{ SEM } & \multicolumn{2}{|c|}{ Significance } \\
\hline & 100:0 & $67: 33$ & 33:67 & $0: 100$ & & Est. & $\mathrm{R}$ & & $\mathrm{D}$ & M \\
\hline $\mathrm{DC}^{\star}$ & 0.0 & 4.3 & 2.9 & $2 \cdot 6$ & 7.08 & - & - & - & 0.9727 & - \\
\hline DMI† & $795^{a}$ & $729^{a, b}$ & $621^{\mathrm{b}, \mathrm{c}}$ & $516^{\mathrm{c}}$ & $47 \cdot 8$ & $625^{\mathrm{b}}$ & $706^{a}$ & $24 \cdot 7$ & 0.0105 & 0.0004 \\
\hline DMI‡ & $835^{a}$ & $764^{\mathrm{a}, \mathrm{b}}$ & $651^{\mathrm{b}, \mathrm{c}}$ & $538^{\mathrm{C}}$ & $50 \cdot 3$ & 687 & 706 & $25 \cdot 9$ & 0.0102 & 0.2609 \\
\hline DMD† & $58 \cdot 6^{\mathrm{a}}$ & $57.6^{\mathrm{a}}$ & $60 \cdot 0^{a}$ & $50 \cdot 4^{\mathrm{b}}$ & 1.97 & $50 \cdot 8^{b}$ & $62 \cdot 5^{\mathrm{a}}$ & 1.34 & 0.0141 & $<0.0001$ \\
\hline DMD‡ & $63^{a}$ & $62 \cdot 2^{\mathrm{a}}$ & $64 \cdot 2^{a}$ & $56 \cdot 2^{\mathrm{b}}$ & 1.68 & $60 \cdot 31$ & 62.5 & 1.14 & 0.0413 & 0.1980 \\
\hline
\end{tabular}

D, diet; M, method; Est., estimated; R, real; DC, diet composition.

$\mathrm{a}, \mathrm{b}, \mathrm{c}$ Values with unlike superscript letters were significantly different between diets or methods $(P<0.05)$

${ }^{*} D C=100 \times($ real - estimated $) /$ real for lucerne intake.

† Values obtained ignoring the recoveries of $\mathrm{C}_{31}$ and $\mathrm{C}_{32}$ in the estimation of intake or assuming a $100 \%$ faecal recovery of $\mathrm{C}_{31}$ in digestibility estimation.

$\ddagger$ Values obtained taking into account the recoveries of $C_{31}$ and $C_{32}$ in the estimation of intake or that of $C_{31}$ in digestibility estimation.

diet on faecal concentration of $n$-alkanes has been previously stated by Dove et $a l .^{(45)}$.

The present work is the first to report incorporation of significant amounts of $n$-alkanes in ruminal bacteria from sheep, suggesting that microbes are able to carry the hydrocarbons either adsorbed to the surface or engulfed. This carrying capacity was previously suggested by Bartley et al. ${ }^{(46)}$ in cattle, working with a shorter-chain alkane $\left({ }^{14} \mathrm{C}\right.$-octadecane). The inability of rumen bacteria to either synthesise or degrade long-chain $n$-alkanes has recently been confirmed in vitro ${ }^{(11)}$. A matter of concern was the possible contamination of bacterial extracts with small digesta particles, but ultramicroscopic observation of dyed preparations from the microbial (LAB) pellets clearly showed the absence of contamination with food particles. It was considered that the SAB fraction would have a greater proclivity for contamination than the LAB fraction, due to the nature of the microbial-detaching process from feed particles; hence, only the latter bacterial extract was analysed. The contribution of LAB-alkanes to the total flow of hydrocarbons to the duodenum (Table 9) ranged from 4 to $8 \%$ for the most abundant alkanes $\left(C_{27}, C_{29}, C_{31}\right.$ and $\mathrm{C}_{33}$ ), and was found to be more variable with diet than the microbial $\mathrm{N}$ flow (Table 2). This was probably due to the fact that intake (and likely $n$-alkanes flow) decreased more markedly than Nmic flow as the proportion of grass increased in the diet.

Previous work ${ }^{(46,47)}$ demonstrated that rumen bacteria are able to incorporate ${ }^{14} \mathrm{C}$-labelled octadecane $\left(\mathrm{C}_{18}\right)$ in their lipids. They also clearly showed that a small fraction of that alkane was absorbed in the small intestine, transported with lipids and incorporated into the body fat deposits, although the greater amount of dosed ${ }^{14} \mathrm{C}_{18}$ (63-81\%) was excreted in faeces. Bacterial metabolism of incorporated alkanes was dismissed because of the absence of radioactivity in VFA, which was also supported by the anaerobic conditions in the rumen. Oxygen is needed to form the $\mathrm{OH}$ group required for the oxidation of $n$-alkanes ${ }^{(48)}$.

Intestinal absorption of significant amounts of plant $n$-alkanes $\left(25 \%\right.$ of $\mathrm{C}_{29}$ ) has been also evidenced in the rat $^{(49,50)}$, leading to the assumption that incomplete faecal recovery of $n$-alkanes in ruminants is due also to absorption in the intestine, but not in the foregut ${ }^{(8,10,11)}$. However, McCarthy ${ }^{(47)}$ found that octadecane was partially converted to the corresponding fatty acid in the ruminal wall during absorption, and he suggested that a similar process might occur with longer-chain $n$-alkanes in sheep. However, the duodenal alkane recovery data shown in Table 8 do not support this comment.

\section{Duodenal and faecal recovery of $n$-alkanes}

Although quite variable, duodenal recovery of dosed evenchain $\left(\mathrm{C}_{32}\right.$ and $\left.\mathrm{C}_{36}\right)$, and of natural odd-chain alkanes present in the diet at high concentrations ( $>27 \mathrm{C}$ atoms) was about $100 \%$ (Table 8), indicating the lack of absorption in the rumen, and was not affected by diet type. The intestinal absorption is in agreement with previous findings ${ }^{(8,9,11)}$. Recoveries of low-concentration $n$-alkanes were biased, with values in general higher than $100 \%$. It is known that small analytical errors are magnified when the concentration of the analysed compound is close to the detection threshold ${ }^{(14)}$, and this is likely to have happened in the present study. Faecal recoveries (Table 10) were always lower than duodenal recoveries, and the extent of bias for faecal recovery of the low-concentration alkanes was lower than the duodenal recovery bias. However, faecal $n$-alkanes present in low concentrations were more subject to large errors than those in high concentrations. Concentration of alkanes at negligible levels in intake was numerically closer to faecal concentration than to duodenal concentration (which was generally much higher). If it is accepted that analytical errors are of the same magnitude with forages and faeces samples, and much higher with forages than with duodenal samples, this would help to explain why duodenal recoveries of low-concentrated $n$-alkanes were much more biased than faecal recoveries.

Although Keli et $a l .{ }^{(19)}$, among others ${ }^{(6,51)}$, support the lack of a diet effect on faecal recovery of $n$-alkanes, this was less clear in the present experiment, with most alkanes (except $\mathrm{C}_{31}, \mathrm{C}_{32}, \mathrm{C}_{33}$ and $\mathrm{C}_{36}$ ) showing decreasing recoveries $(P<0.05)$ as the proportion of ryegrass in the diet increased. Level of intake is known to affect faecal recovery of $n$-alkanes ${ }^{(15)}$, and in the present work, intake also decreased 
linearly with ryegrass proportion (Table 2). Faecal recoveries of natural alkanes in the present experiment were lower than those reported by Keli et al. ${ }^{(19)}$ working with the same feedstuffs, and this highlights the importance of estimating recoveries for each individual experiment. In this particular case, discrepancies could be due to the lower intake of cannulated animals, which is known to affect faecal recovery of $n$-alkanes ${ }^{(15)}$. Individual variability is also known to have a great importance ${ }^{(20)}$. In the case of dosed alkanes $\left(\mathrm{C}_{32}\right.$ and $\mathrm{C}_{36}$ ), they both had similar faecal recoveries within diets, although there was a variation between diets (Table 10). Differences from values reported by Keli et al. ${ }^{(19)}$ were minimal. The different behaviour of natural and dosed alkanes has been attributed to variations in their rate of passage, as synthetic hydrocarbons are more associated to the liquid phase of the digesta, whereas natural alkanes are more associated to the solid phase ${ }^{(8)}$.

\section{Estimation of diet composition, intake and digestibility}

The accuracy of diet composition estimates using the $n$-alkane technique is linked to (1) the existence of alkane profiles different enough to be discriminant and (2) the previous knowledge of individual faecal recoveries of those hydrocarbons involved in the calculation ${ }^{(7,52)}$. In the present experiment, the profiles of lucerne and ryegrass were different enough, and the results of discriminant analysis showed that $\mathrm{C}_{30}, \mathrm{C}_{31}$ and $\mathrm{C}_{33}$ were the three alkanes with higher potential of discrimination between both ingredients. Only $\mathrm{C}_{31}$ and $\mathrm{C}_{33}$ were included in the calculations due to the low faecal concentration of $\mathrm{C}_{30}$, and hence the risk of larger errors. Average faecal recovery of each alkane for all diets was employed in the present experiment due to the lack of differences (Table 10) between diets. Using this approach, the discrepancies between observed and estimated values were small (less than $5 \%$ in the worst case, that of diet 67:33; Table 11), although individual variation was high $(\operatorname{sem}=7 \cdot 08)$. The use of individual recovery factors usually increases the accuracy of estimations ${ }^{(20)}$, but this approach is not advisable in grazing conditions, where errors associated to the estimation of individual faecal recoveries may be large $e^{(20)}$

Estimation of intake using adjacent alkanes ${ }^{(6)}$ assumes the same recovery for both of them (generally natural $\mathrm{C}_{31}$ and dosed $\mathrm{C}_{32}$ ). However, in the present experiment, differences in faecal recovery between $C_{31}$ and $C_{32}$ ranged from 5 to $10 \%$ depending on diet, which lead to errors of similar extent in the intake estimates when equal recoveries for the two markers are assumed ${ }^{(52)}$. Therefore, an increase in the accuracy of estimates may be obtained using separate recoveries for each alkane, such as the average value for all diets. This has been recently stated in both sheep ${ }^{(19)}$ and beef cattle ${ }^{(53)}$

Digestibility was also calculated assuming 100\% faecal recovery of $\mathrm{C}_{31}$, or including the actual value in the calculations. As previously stated, the latter option increased the accuracy of the estimations.

One important point to emphasise is that, although the contribution of LAB alkanes to the total flow of hydrocarbons to the duodenum ranged from 4 to $8 \%$ (Table 9), this seemed irrelevant for diet composition/intake estimates (Table 11). Total faecal alkanes are used for these estimates, regardless of the digesta fraction where these hydrocarbons 'reside'; hence, the presence of these latter in LAB does not seem to affect the accuracy of the alkane procedures for estimating diet composition and intake.

\section{Conclusions}

Losses of $n$-alkanes in the gut of sheep take place post-ruminally, with diet type (different proportions of lucerne and ryegrass) not having a significant influence on the complete duodenal recovery. By contrast, faecal recovery was incomplete and affected by diet to a different extent depending on the $n$-alkane considered.

An important finding of the present work was that rumen bacteria (LAB) may carry dietary $n$-alkanes to an extent, which is linked to diet type, although this does not affect the accuracy of the alkane procedures for estimating diet composition and intake. The mechanisms of and the reasons for this incorporation are unknown.

The proportion of NI recovered as NAN in the duodenum increases with the proportion of grass in the diet, and in the present work, it was complete for a $\mathrm{NH}_{3}$ concentration in the rumen below approximately $110 \mathrm{~g} / 1$ (equivalent to a $\mathrm{CP}$ concentration of $100 \mathrm{~g} / \mathrm{kg}$ DOM). This suggests that not only the plants' CP concentration is important in determining the net transfer of ingested protein to the duodenum, but also its rate of degradation. Exploring ways of reducing it may be worthy, at least in the particular case of lucerne. Such an approach should not have any deleterious effect on efficiency of synthesis of microbial protein.

\section{Acknowledgements}

A. K. was awarded a fellowship of the 'Plan de Formación de Personal Investigador (FPI)' from the Spanish Ministry for Education and Science, and G. O. was awarded a fellowship from the 'Asociación Nacional de Universidades e Instituciones de Educación Superior (ANUIES) de la Republica Mexicana, Programa Nacional de Superación del Personal Académico'. The skilled technical assistance of Dr Mariano Mota, Miss Cristina López, Mr Ángel Barceló and Miss Ana Herrero is also gratefully acknowledged. The present work was part of the PhD project of A. K., whose supervisor A. d. V. G. O. helped to carry out most alkane, data and statistical analysis, and J. A. G. was involved in the study design and drafting of the manuscript. There are no conflicts of interest in relation to the present paper. The present work was funded by the Spanish Ministry for Education and Science (project no. AGL2001-2771).

\section{References}

1. Poppi DP \& McLennan SR (1995) Protein and energy utilization by ruminants at pasture. J Anim Sci 73, 278-290. 
2. Janovick NA, Russell JR, Strohbehn DR, et al. (2005) Grazing and feedlot performance of yearling stocker cattle integrated with spring- and fall-calving beef cows in a year-round grazing system. J Anim Sci 83, 2696-2704.

3. Huhtanen P, Rinne M \& Nousiainen J (2007) Evaluation of the factors affecting silage intake of dairy cows: a revision of the relative silage dry-matter intake index. Animal 1, $758-770$.

4. Moorby JM, Lee MRF, Davies DR, et al. (2009) Assessment of dietary ratios of red clover and grass silages on milk production and milk quality in dairy cows. J Dairy Sci $\mathbf{9 2}$, $1148-1160$.

5. Mikolayunas C, Thomas DL, Armentano LE, et al. (2011) Effect of rumen-undegradable protein supplementation and fresh forage composition on nitrogen utilization of dairy ewes. J Dairy Sci 94, 416-425.

6. Mayes RW, Lamb CS \& Colgrove PM (1986) The use of dosed and herbage $n$-alkanes as markers for the determination of herbage intake. J Agric Sci 107, 161-170.

7. Mayes RW \& Dove H (2006) The use of $n$-alkanes and other plant-wax compounds as markers for studying the feeding and nutrition for large mammalian herbivores. In The Assessment of Intake, Digestibility and the Roles of Secondary Compounds. BSAS Publication no. 34, pp. 153-182 [CA Sandoval-Castro, FD de B Hovell, F Torres Acosta and A Ayala-Burgos, editors]. Nottingham: Nottingham University Press.

8. Mayes RW, Lamb CS \& Colgrove PM (1988) Digestion and metabolism of dosed even-chain and herbage odd-chain $n$-a1kanes in sheep. In Proceedings of the 12th General Meeting of the European Grass1and Federation, Dublin, Ireland, pp. 159-163.

9. Kafilzadeh F \& Parker DS (1990) The use of $n$-alkanes as indigestible markers in studies on intestinal digestion in sheep. Anim Prod 50, 578-579.

10. Ohajuruka OA \& Palmquist DL (1991) Evaluation of $n$-alkanes as digesta markers in dairy cows. J Anim Sci 69, $1726-1732$.

11. Keli A, Mayes RW \& de Vega A (2008) In vitro studies of the metabolism of $\left[{ }^{14} \mathrm{C}\right]-n$-alkanes using ruminal fluid of sheep as substrate. Animal 2, 1748-1752.

12. Askar AR, Guada JA, Balcells J, et al. (2005) Validation of use of purine bases as microbial marker by ${ }^{15} \mathrm{~N}$ labelling in growing lambs given high-concentrate diets: effects of grain processing, animal age and digesta sampling site. Anim Sci 81, 57-65.

13. Giráldez FJ, Lamb S, López S, et al. (2004) Effects of carrier matrix and dosing frequency on digestive kinetics of evenchain alkanes and implications on herbage intake and rate of passage studies. J Sci Food Agric 84, 1562-1570.

14. Elwert C (2004) Studies on the use of alkanes to estimate diet composition, intake and digestibility in sheep. PhD Thesis, Martin-Luther Universität Halle-Wittenberg.

15. Stakelum G \& Dillon P (1990) Dosed and herbage alkanes as feed intake predictors with dairy cows: the effect of feeding level and frequency of perennial ryegrass. In Proceedings of the VII European Grazing Workshop, October 1990, Wageningen, Netherlands,

16. Martin C, Williams AG \& Michalet-Doreau B (1994) Isolation and characteristics of the protozoal and bacterial fractions from bovine ruminal contents. J Anim Sci 72, 2962-2968.

17. Downes AM \& McDonald IW (1964) The chromium-51 complex of ethylenediamine tetraacetic acid as a soluble rumen marker. Br J Nutr 18, 153-162.
18. de Vega A \& Poppi DP (1997) Extent of digestion and rumen condition as factor affecting passage of liquid and digesta particles in sheep. J Agric Sci 128, 207-215.

19. Keli A, Andueza D, de Vega A, et al. (2008) Validation of the $n$-alkane and NIRS techniques to estimate intake, digestibility and diet composition in sheep fed mixed lucerne:ryegrass diets. Livestock Sci 119, 42-54.

20. Valiente OL, Delgado P, de Vega A, et al. (2003) Validation of the $n$-alkane technique to estimate intake, digestibility, and diet composition in sheep consuming mixed grain:roughage diets. Aust J Agric Res 54, 693-702.

21. Mertens DR (2002) Gravimetric determination of amylasetreated neutral detergent fibre in feeds with refluxing beakers or crucibles: collaborative study. J Offic Assoc Chem Int 85, 1217-1240.

22. Association of Official Analytical Chemists (AOAC). (2005) Official Methods of Analysis of AOAC International, 18th ed. Gaithersburg, MD: AOAC.

23. Robertson JB \& Van Soest PJ (1981) The detergent system of analysis. In The Analysis of Dietary Fibre in Food, pp. 123-158 [WPT James and O Theander, editors]. New York: Marcel Dekker.

24. Jouany JP (1982) Volatile fatty acid and alcohol determination in digestive contents, silages juices, bacterial cultures and anaerobic fermentor contents. Science des Aliments 2 131-144.

25. Chaney AL \& Marbach EP (1962) Modified reagents for determination of urea and ammonia. Clin Chem 8, 130-132.

26. Ørskov ER \& McDonald I (1979) The estimation of protein degradability in the rumen from incubation measurements weighted according to rate of passage. J Agric Sci 92, 499-503.

27. Faichney GJ (1975) The use of markers to partition digestion within the gastro-intestinal tract of ruminants. In Digestion and Metabolism in the Ruminant, pp. 277-291 [IW McDonald and ACI Warner, editors]. Armidale, NSW: University of New England.

28. Mayes RW, Beresford NA, Lamb CS, et al. (1994) Novel approaches to the estimation of intake and bioavailability of radiocaesium in ruminants grazing forested areas. Sci Tot Environ 157, 289-300.

29. Dove H \& Milne JA (1994) Digesta flow and rumen microbial protein production in ewes grazing perennial ryegrass. Aust J Agric Res 45, 1229-1245.

30. Kaps M \& Lamberson W (2004) Biostatistics for Animal Science. Wallingford: CABI Publishing.

31. Bocquier F, Theriez M, Prache S, et al. (1988) Alimentation des ovins (Feeding of sheep). In Alimentation des bovins, ovins et caprins (Feeding of Cattle, Sheep and Goats), pp. 249-271 [R Jarrige, editor]. Paris: INRA Editions.

32. National Research Council (2000) Nutrient Requirements of Beef Cattle. Washington, DC: National Academy Press.

33. Aitchison EM, Gill M, Dhanoa MS, et al. (1986) The effect of the digestibility of forage species on the removal of digesta from the rumen and the voluntary intake of hay by sheep. Br J Nutr 56, 463-476.

34. Institut National de la Recherche Agronomique (1988) Alimentation des bovins, ovins et caprins (Feeding of Cattle, Sheep and Goats) [R Jarrige, editor]. Paris: INRA Editions.

35. Colucci PE, Chase LE \& Van Soest PJ (1982) Feed intake, apparent diet digestibility, and rate of particulate passage in dairy cattle. J Dairy Sci 65, 1445-1456.

36. Cruickshank GJ, Poppi DP \& Sykes AR (1992) The intake, digestion and protein degradation of grazed herbage by early weaned lambs. Br J Nutr 68, 349-364. 
37. Stewart GS \& Smith CP (2005) Urea nitrogen salvage mechanisms and their relevance to ruminants, non-ruminants and man. Nutr Res Rev 18, 49-62.

38. Satter LD \& Slyter LL (1974) Effect of ammonia concentration on rumen microbial protein production in vitro. Br J Nutr 32, 199-204.

39. Balcells J, Guada JA, Castrillo C, et al. (1993) Rumen digestion and urinary excretion of purine derivatives in response to urea supplementation of sodium-treated straw fed to sheep. Br J Nutr 69, 721-732.

40. Pérez JF, Balcells J, Guada JA, et al. (1997) Rumen microbial production estimated either from urinary purine derivative excretion or from direct measurements of ${ }^{15} \mathrm{~N}$ and purine bases as microbial markers: effect of protein source and rumen bacterial isolates. Anim Sci 65, 225-236.

41. Agricultural Research Council (1980) The Nutrient Requirements of Ruminant Livestock. Wallingford: CABI Publishing.

42. Owens FN \& Goetsch AL (1986) Digesta passage and microbial protein synthesis. In Control of Digestion and Metabolism in Ruminants, pp. 196-223 [LP Milligan, WL Grovum and A Dobson, editors]. Englewood Cliffs, NJ: Prentice-Hall.

43. Robinson PH, Sniffen CJ \& Van Soest PJ (1985) Influence of level of feed intake on digestion and bacterial yield in the forestomachs of dairy cattle. Can J Anim Sci $\mathbf{6 5}$, 437-444.

44. Kennedy PM \& Milligan LP (1978) Effects of cold exposure on digestion, microbial synthesis and nitrogen transformations in sheep. BrJ Nutr 39, 105-117.

45. Dove H, Mayes RW \& Freer M (1996) Effect of species, plant part, and plant age on the $n$-alkane concentrations in the cuticular wax of pasture plants. Aust I Agric Res 47 , $1333-1347$

46. Bartley EE, Helmer LG \& Meyer RM (1971) Metabolism of ${ }^{14}$ C-labelled octadecane by cattle. J Anim Sci 33, 1351-1355.

47. McCarthy RD (1964) Mammalian metabolism of straight chain saturated hydrocarbons. Biochim Biophys Acta 84, 74-79.

48. Sporman AM \& Widdel F (2000) Metabolism of alkylbenzenes, alkanes, and others hydrocarbons in anaerobic bacteria. Biodegradation 11, 85-105.

49. Tulliez JE \& Bories GF (1975) Métabolisme des hydrocarbures paraffiniques et naphténiques chez les animaux superieurs. I. Retention des paraffines (normal, cyclo et ramifiées) chez le rat (Metabolism of paraffinic and naphthenic hydrocarbons in higher animals. I. Retention of paraffins (normal, branched and cyclo) in rats). Ann Nutr Alimen 29, 201-211.

50. Tulliez JE \& Bories GF (1975) Métabolisme des hydrocarbures paraffiniques et naphténiques chez les animaux supérieurs. II. Accumulation et mobilisation chez le rat (Metabolism of paraffinic and naphthenic hydrocarbons in higher animals. II. Accumulation and mobilization in the rat). Ann Nutr Alimen 29, 213-221.

51. Brosh A, Henking Z, Rothman SJ, et al. (2003) Effects of faecal $n$-alkane recovery in estimates of diet composition. J Agric Sci 140, 93-100.

52. Dove H \& Mayes RW (1996) Plant wax components: a new approach to estimating intake and diet composition in herbivores. J Nutr 126, 13-26.

53. Oliván M, Ferreira LMM, Celaya R, et al. (2007) Accuracy of the $n$-alkane technique for intake estimates in beef cattle using different sampling procedures and feeding levels. Livest Sci 106, 28-40. 